\title{
Conversational Implicatures on Saturday Night Live Talk Show
}

\author{
Sri Yulianti \\ English Language Studies Postgraduate Program, Faculty of Cultural Sciences, Hasanuddin University, Makassar, \\ Indonesia \\ Burhanuddin Arafah \\ English Department, Faculty of Cultural Sciences, Hasanuddin University, Makassar, Indonesia \\ Ummu Rofikah \\ English Language Studies Postgraduate Program, Faculty of Cultural Sciences, Hasanuddin University, Makassar, \\ Indonesia \\ Andi Muhammad Syafri Idris \\ English Language Studies Postgraduate Program, Faculty of Cultural Sciences, Hasanuddin University, Makassar, \\ Indonesia \\ Nurfaizah Samsur \\ English Language Studies Postgraduate Program, Faculty of Cultural Sciences, Hasanuddin University, Makassar, \\ Indonesia
}

\author{
Azhariah Nur B. Arafah \\ Faculty of Psychology, Universitas Gunadarma, Indonesia
}

\begin{abstract}
Conversational implicature seems to be an everlasting concern in pragmatics for its wide-ranging investigation possibility. Applying Gricean's principles, the present study examined the types of conversational implicatures found in the Saturday Night Live talk show. This research used a qualitative method with a pragmatic approach. The research data were collected from the utterances in Season 46 Episode 5 accessed from MBC's channel (www. saturday night live - NBC.COM). The result indicated that there were two types of conversational implicatures found in Saturday Night Live talk show namely: First, particularized conversational implicature, and second, generalized conversational implicature. We found that the utterances containing particularized implicature outnumbered the ones with generalized implicature. In our interpretation, the dominance of particularized implicature reflects the centrality of the particular context in producing and inferring utterances for meaningful and effective communication.
\end{abstract}

Index Terms - conversational implicatures, types of conversational implicatures, Saturday Night Live, talk show

\section{INTRODUCTION}

In an effective talk exchange, both speakers and listeners are assumed to communicate effectively by producing and inferring utterances based on agreed logical principles. Grace (1975), a language philosopher, set a standard of global imperatives in producing rationally effective utterances called cooperative principle which comprises of four maxims i.e. the maxim of quantity: make your conversational contribution informative, the maxim of quality: be true and evidencebased, the maxim of relevance: be relevant with the context, and maxim of manner: avoid ambiguity and be perspicuous. To cooperate well in communication, a speaker is assumed to adhere to this set of principles in producing his utterances. Green (1990) noted that Grice's concept of cooperative principle contributes much in the study of implied meaning for its role as the baseline the hearers use to infer the utterances which meaning conform with the maxims, to recognize the utterances that deviate the maxims, and to interpret the deviations per se. Thus, adherence to cooperative principles allows both speakers and listeners to have collaborative roles in thinking about what the other has in mind (Yule, 1996).

But interestingly, a speaker can also communicate meaning in a uniquely distinct pattern and manner from what he means. Quite often, we find messages sent to hearers in a way that is at a glance irrelevant to the literal meaning. The message conveyed will be meaningful and give more information if it is observed in its context (Arafah, Thayyib, Kaharuddin, \& Sahib, 2020.) As a result, only readers or people who read the message with high motivation will lead to achieving more information about it (Arafah et.al, 2020). Viewing from Grice's concept of cooperative principles, those utterances have violated the maxims of effective communication. To this extent, language works beyond its structural 
function, and context contributes much to the interpretation of meaning (Kamrida, Yassi, Arafah, Imran, 2016). To understand the meaning, we cannot solely rely on the literal language, but consider the intentional, inferential, and interactional aspects (Sperber and Wilson, 1986; Clark, 1996 in Levinson, 2000a). Sometimes, speakers also use words or utterances to perform an act (Arafah \& Kaharuddin, 2019). Thus, many utterances may have rich pragmatics implications and potentialities that can only be understood when linked to contextual appropriateness.

Grice (1975) called the type of utterance in which the speaker deviates the cooperative principle in expressing his meaning as a conversational implicature. Grice (1975) was the first to coin this term and introduce it to the field of philosophy of language. He distinguished between 'say' and 'implicate' where the latter means to communicate something beyond the literal meaning of the language used. Griffiths (2006) defined implicature as giving inferences depending on standards existing for the utilization of language, such as the amplified agreement that speakers have to point the real information when they communicate. Yule, (1996: 36) also added that implicature is a primary example of "more being communicated than is said". Thus, it can be said that implicature is the speakers' choice of utterance that violates the maxims of cooperative principles to communicate implied meaning that can only be inferred by the hearer based on the contextual consideration.

Mey (2004) stated that conversational implicature is something that is inferred in conversation or it is intention inferred. In other words, conversational implicature is the meaning that is not conveyed directly but implied in utterances. Conversational implicatures occur when violating the maxims of the cooperative principle. These maxims are considered to be violated if the following conditions happen in an utterance. Firstly, violating the maxim of quality happens if the speaker gives information that is not true and unproven. Secondly, violating the maxim of quantity occurs if the speaker gives more or less information. It means that information must be following what is needed by the speaker (Thomas, 1995). Thirdly, violating the maxim of relevance happens if the speaker gives information that is not relevant to the ongoing context (Cutting, 2002). Finally, violating the maxim of manner happens if the speaker gives information that is not clear or ambiguous (Cutting, 2008).

The concept of implicature has provoked some linguists to scrutinize and even challenge the concept. Those who follow Gricean's view that linguistic communication should be interpreted by considering more than literal meaning dedicated their works to illuminate this issue (e.g. Levinson, 1983; Mey, 1993; Green, 2012; Yule, 1996; Thomas, 1995; Vershueren, 1999). Yule (1996) helped to provide an easier path to better understand the concept. Levinson (1983, 2000b) and Horn (1988) provided a comprehensive explanation regarding implicature and its types. Lindblom (2001) conducted a cross-disciplinary survey of uses of cooperative principles. Davis (1998) and Lindblom (2001) scrutinized and criticized the concept of conversational implicature regarding the full range of meanings within implicature. Additionally, conversational implicature has been the center of an investigation in several studies such as the works of Alfina (2016) and Virgin \& Utami (2016) that identified conversational implicatures by analyzing maxim violation. However, the two latter studies were focused on analyzing implicature in general without classifying it into specific types as Grice's classification. Thus, the present study aims to fill the gap by analyzing the specific types of conversational implicature found in utterances in Saturday Night Live talk show posted on an internet platform.

Saturday Night Live talk show is one of the popular talk shows in the United States comprising verbal communication uttered by a host and some guests. The show does not only screen on a national TV channel but also some sites on the internet. Arafah and Hasyim (2019) stated that internet media content is most frequently visited as a communication medium. Hence the show is a prominent communication medium to be observed.

Levinson (1983, p. 285) argued that "the proper way to study conversational organization is through empirical techniques". It is therefore one of our rationales to conduct the present study - to capture all implicature phenomena found in Saturday Night Live talk show, an occasion where talk exchanges occur among native speakers of English. Other studies focus on analyzing conversational implicatures in Talk Show contained generalized and particularized conversational implicatures. However, the present study scrutinized deeper the choices of utterance in the Saturday Night Live talk show to know the preference of using implicature and draw a conclusion from it.

\section{LITERATURE REVIEW}

\section{A. Grice's Cooperative Principles}

Effective communication is the main building block of human interaction. As communication is vital in information exchange and in building social relationships, people should follow logical conversational patterns and procedures to avoid misinterpretation. Grice (1975) proposed a set of global imperatives to speakers in producing logically effective utterances called cooperative principles. A cooperative principle is a set of directives in producing and understanding utterances effectively. Adherence to this principle allows the communicants to "operate together" in the meaning exchange process. The cooperative principle does not only govern how a speaker is assumed to formulate their utterances, but also performs as the baseline of the hearer to understand the intention of the speaker. According to Crowley \& Mitchell (1994), in communication, speakers and listeners are supposed to respond to each other in their turn and exchange the needed information which benefits both. Cooperative principles work on this purpose. Grice (1975) introduced a concept of cooperative principle, highlighted, "make your conversational commitment what is needed, at the stage at which it happens, by the acknowledged aim or heading of the conversation exchange in which you're engaged". To do so, here are the four maxims of cooperative principles: 
1) Maxim of Quantity

A speaker is expected to make a conversational contribution as informative as is required. In other words, the maxim of quantity emphasizes the speaker to say only what is needed or requested by the hearer, not too much or less. For instance:

A: "Where's your daddy, Anna?"

B: "My daddy is home"

In the example above, B answers A's question by giving the information that is required by A.

2) Maxim of Quality

A speaker should give true information which can be proof in real life. Besides, the speaker should know that the hearer expected him to honor the maxim if the speaker follows this maxim. Other maxims will be considered less true without the maxim of quality. For instance:

A: "How many maxims Grice mentioned in his book?

B: "There are four maxims"

In the example above, B gives true information to A's question which can be seen and proven in Grice's book stated that there are four maxims.

3) Maxim of Relevance

A speaker should give information relevant to the ongoing context. For instance:

A: "Hello, is anybody home?"

B: "I' $m$ in the toilet"

In the example above, B gives the answer which is not relevant to A's question. By answering A's question, A is expected to understand that $\mathrm{B}$ cannot open the door.

4) Maxim of Manner

Speaker should give clear information, avoid ambiguity and unnecessary prolixity. For instance:

A: "So since you're holding a detached but animated head... do you ever use it, like, to ......you know?"

B: "To what?"

In the example above, B gives unclear information to A's question. B did not answer A's question but B gave another question.

Nevertheless, as stated by Grice (1975), periodically, the cooperative principles are violated by people in their communication, particularly when the speakers proposed to communicate their intentions indirectly or point to convince audience members to draw a few inferences from their expressions. For occasion, when someone makes a joke, writes a book, makes a movie, or is locked in neighborliness circumstances, he may abuse one or a few sayings to influence the questioner and take off a successful impression on them (Sobhani \& Saghebi, 2014).

\section{B. Conversational Implicatures}

Despite the concept of cooperative principles, people's utterances in talk exchanges do not always adhere to those conversational directives and may flout the maxims of cooperative principles for several purposes. This linguistic phenomenon called 'conversational implicature' was firstly brought by Grice to the concern of the philosophy of language in 1975. Conversational implicatures can be interpreted as context-dependent and non-truth conditional concepts (Birner, 2012). This concept is characterized by the Oxford lexicon (Gem, 2008) as "The activity of inferring a meaning past the strict sense of what is unequivocally stated." Encourage, conversational implicature is considered to be one of the key issues within the field of down to business competence and discussion investigation (Safont, 2005; Wishnoff, 2000).

The idea of conversational implicatures is determined from common standards of the discussion furthermore a few adages visitors will ordinarily comply (Brown and Yule, 1983). Similarly, Paltridge (2006) explained that conversational implicatures referred to the induction where a listener makes around a speaker's aiming meaning that emerges from their utilization of the strict meaning of what the speaker said, the conversational rule, and its maxims. Further, conversational implicature occurs since an utterance implies the form of proposition which is neither part nor consequence of the utterance (Gunarwan, 1994).

Grice (1975) differentiated conversational implicature into particularized and generalized implicatures. Particularized conversational implicature depends on specific relevant highlights whereas generalized conversational implicature is about to be more disputable and at the same time more profitable for philosophical purposes since they will be implicatures that would be carried by an expression of a certain frame, even though, as with all implicatures, they are not to be spoken to as portion of the routine meaning of the words or shapes in address (Grice, 1981). However, Levinson (2000a:13) stated, "none of these distinctions is straightforward". To shed light on this issue, several publications such as Levinson (1983, 2000b), Horn (1988), and Yule (1996) provide comprehensive guides to understand Grice's theory of implicature and its key distinctions.

\section{Generalized Conversational Implicatures}

Grice" declares that generalized conversational implicature is implicature that emerges without any specific setting or uncommon situation being vital (Grundy, 2000). Yule (1996) famous, "When no extraordinary information is required 
within the setting to calculate the extra passed on meaning, it is called generalized conversational implicature. For instance:

Charlene: I hope you brought the bread and the cheese.

Dexter: Ah, I brought the bread.

The exchange above implies that Dexter did not buy cheese.

Another example of generalized implicature that shows a direct answer to a question is:

A: what happened to John after college?

B: John got a good job and got married.

Within the possible settings for the case over, the sentences hitched after he got a great job. Since speaker A is addressing data almost Dave and listener B reacted to the address specifically the data that John got a job at that point he got hitched. The expressions can be classified into generalized conversational implicature since the setting is as of now given from the address emerge.

\section{Particularized Conversational Implicatures}

A particularized conversational implicature depends on specific highlights of the setting. According to Yule (2006), particularized conversational implicature is a conversation that takes place in a specific context where the listener assumes information locally. Context contribution to efforts to produce conversational implicatures allows expressing meanings that are ironic, metaphorical, hyperbole, rejection, request, and accusation. Moreover, all implicatures that emerge from the proverb of pertinence are particularized for articulations are important as it were concerning the specific point or issue at hand. Lakoff (1989) argued that particularized conversational implicature is implicature that needs context or cultural understanding. Particularized implicature is a conversational implicature that is derivable only in a specific context. Similarly, Levinson (1983) said that particularized conversational implicature is a type of conversational implicature with does require such specific context. For example:

A: "I'm so sorry for making you wait for a long time"

B: "That's fine, it is just like waiting for one year"

In the context of this exchange, speaker A requests an apology for making B waiting for him for a long time. The response of B "that's fine" does not mean that she is fine, but it implies her anger and this is emphasized by her saying "it is just like waiting for one year" which accentuates her feeling of boredom. This utterance is classified as particularized implicature since it can only be understood by seeing the local situation and the typical language used in one particular place.

The conversational implicature can be observed by seeing the deviation of maxims of cooperative principles. Further, implicature can be interpreted by initially observing which maxims of cooperative principles have been violated in the utterances and relate it to the context where the ongoing talks occur. Thus, Green (1990) highlighted the multifaceted contribution of Grice's concept of the cooperative principles to the study of pragmatics as it is integral as a standard for interpreting utterances that conform with them and a baseline not only for recognizing utterances that deviate from standard practice but also for interpreting such deviations.

\section{Methodology}

As noted by Hasjim et al. (2020), "every research project must use a method, both in collecting and in analyzing the data". This research used the qualitative research method. Subjective strategies emphasize the perception of wonders and center more on the substance of the meaning of these marvels (Kaharuddin, \& Rahmadana, 2020). The investigation and instinct of subjective investigation are unequivocally influenced by the quality of the words and the utilization of sentences.

Qualitative research is an exploratory research (Arafah \& Hasyim, 2019; Arafah \& Hasyim, 2020). This provides insights into the problem or helps to develop ideas or hypotheses (Hasyim et al, 2020). In using this methodology, we explained the implicature phenomena which happen in the talk show by collecting the entire information in detail. In this research, the data were words, phrases, sentences, and descriptions. As qualitative research, the data processing involved no statistical approach (Purwaningsih, et al, 2019).

The research procedure comprised of some steps i.e. Firstly, downloading the video of Saturday Night Live talk show Season 46 Episode 5 on MBC's channel (the latest video at the time when this study was conducted); Secondly, watching the video and transcribing the expressions within the video into the composed content; Thirdly, perusing the deciphered expressions carefully and deciding which sorts of conversational implicatures they have a place based on Grace's theory of Cooperative Principle and his classification of conversational implicature, and Finally, concluding the data analysis.

\section{FINDINGS AND DisCUSSION}

\section{A. Findings}

After conducting the analysis, we found 50 data containing conversational implicatures on Saturday Night Live talk show Season 46 Episode 5. The data were identified and classified based on the types of conversational implicatures 
using Grice's theory of conversational implicatures. 21 data were containing generalized conversational implicatures and 29 data containing particularized conversational implicatures. The following table summarizes the types of conversational implicatures we found in the talk show.

TABLE 1

TYPES OF CONVERSATIONAL IMPLICATURES

\begin{tabular}{|c|c|c|c|c|}
\hline \multirow[t]{2}{*}{ No } & \multirow[t]{2}{*}{ Utterances } & \multirow[t]{2}{*}{ Implicatures } & \multicolumn{2}{|c|}{$\begin{array}{l}\text { Types of Conversational } \\
\text { Implicatures }\end{array}$} \\
\hline & & & GCI & PCI \\
\hline 1. & We lost before. & $\begin{array}{l}\text { A classic poem by Edgar Allan Poe "The Raven" } \\
\text { is one of the famous scary stories in the 1800s. }\end{array}$ & $\sqrt{ }$ & \\
\hline 2. & Not Michael Moore. & $\begin{array}{l}\text { Michael Moore is an American left-wing } \\
\text { documentary filmmaker, author, and activist } \\
\text { whose works frequently address the topic of } \\
\text { globalization and capitalism. }\end{array}$ & & $\sqrt{ }$ \\
\hline 3. & Just like Al Gore. & $\begin{array}{l}\text { Joe Biden will face difficulties to be the winner } \\
\text { of the next US presidential election. }\end{array}$ & & $\sqrt{ }$ \\
\hline 4. & $\begin{array}{l}\text { But your real advantage is you're not a } \\
\text { woman, you're a man! }\end{array}$ & $\begin{array}{l}\text { Man will have some difficulties in debating with } \\
\text { the woman. }\end{array}$ & & $\sqrt{ }$ \\
\hline 5. & I was wrong before. & The previous information is not true. & $\sqrt{ }$ & \\
\hline 6. & Oh! & Jim did not accept the result. & & $\sqrt{ }$ \\
\hline 7. & $\begin{array}{l}\text { Our country's not haunted. We just have to } \\
\text { come together like two butt cheeks, and stop } \\
\text { the crack. }\end{array}$ & $\begin{array}{l}\text { Americans needed to stick together to keep their } \\
\text { country on good terms. }\end{array}$ & & $\sqrt{ }$ \\
\hline 8. & Taxes. & Americans have a problem related to taxation. & & $\sqrt{ }$ \\
\hline 9. & That's right. & $\begin{array}{l}\text { He agreed that Donald Trump had a platinum } \\
\text { plan where it consists of "A promise to black } \\
\text { Americans for } 4 \text { years". }\end{array}$ & & $\sqrt{ }$ \\
\hline 10. & $\begin{array}{l}\text { Trump cannot win. We must do better than } \\
\text { that spray tan super-spreader. I will win } \\
\text { because I'm a baller. }\end{array}$ & Joe Biden is better than Donald Trump. & & $\sqrt{ }$ \\
\hline 11. & I know. & $\begin{array}{l}\text { Kamala is an American politician and the first } \\
\text { female vice president. }\end{array}$ & $\sqrt{ }$ & \\
\hline 12. & $\begin{array}{l}\text { Well, no, this is just a very common and } \\
\text { normal condition called old man purple. }\end{array}$ & $\begin{array}{l}\text { There will be many strange diseases that arise } \\
\text { when we are getting older. }\end{array}$ & & $\sqrt{ }$ \\
\hline 13. & Oh yeah! & $\begin{array}{l}\text { In the presidential election, Americans should } \\
\text { use their votes so democracy will represent. }\end{array}$ & & $\sqrt{ }$ \\
\hline 14. & Birds! & She was attached by many birds. & $\sqrt{ }$ & \\
\hline 15. & $\begin{array}{l}\text { It means birds. The fluffy flutty things. } \\
\text { They're trying to kill everybody. }\end{array}$ & $\begin{array}{l}\text { The birds around the public telephone tried to } \\
\text { attack people. }\end{array}$ & & $\sqrt{ }$ \\
\hline 16. & $\begin{array}{l}\text { No, no, there's too many of them and they're } \\
\text { too mean. }\end{array}$ & She was just alone on a public telephone. & $\sqrt{ }$ & \\
\hline 17. & $\begin{array}{l}\text { No, no, they're seagulls. You know the little } \\
\text { guys that eat french fries at the beach. }\end{array}$ & $\begin{array}{l}\text { The seagull is a kind of bird that can give a lot of } \\
\text { viruses. }\end{array}$ & & $\sqrt{ }$ \\
\hline 18. & $\begin{array}{l}\text { I'm very sorry I doubted you. The birds are } \\
\text { trying to be very mean. }\end{array}$ & $\begin{array}{l}\text { The birds around the public telephone were } \\
\text { uncontrollable. }\end{array}$ & $\sqrt{ }$ & \\
\hline 19. & $\begin{array}{l}\text { Oh, an egg! It's trying to be nice so we have } \\
\text { breakfast. }\end{array}$ & Eggs are suitable food for breakfast. & $\sqrt{ }$ & \\
\hline 20. & $\begin{array}{l}\text { I don’t know. Dammit!! I don't know, but } \\
\text { kiss me. }\end{array}$ & He did not care about the situation around them. & & $\sqrt{ }$ \\
\hline 21. & $\begin{array}{l}\text { My god, it's the headless horseman. The one } \\
\text { I've heard tell of in ghastly stories. }\end{array}$ & A headless horseman existed in the past. & $\sqrt{ }$ & \\
\hline 22. & For eternity. & $\begin{array}{l}\text { The head and the neck cannot be connected } \\
\text { again. }\end{array}$ & & $\sqrt{ }$ \\
\hline 23. & To what? & Refusing John's question & & $\sqrt{ }$ \\
\hline 24. & $\begin{array}{l}\text { Okay, look. I've been trying to do it to } \\
\text { myself with my regular attached head. I tried } \\
\text { yoga and stretching. I even had the town } \\
\text { doctor remove two of my ribs. }\end{array}$ & Normal people can do many things by the head. & & $\sqrt{ }$ \\
\hline 25. & Excuse me? & Beck refused to answer that kind of question. & & $\sqrt{ }$ \\
\hline 26. & He already asked that. & $\begin{array}{l}\text { Beck tried to turn William's attention to another } \\
\text { topic. }\end{array}$ & $\sqrt{ }$ & \\
\hline 27. & I have real teeth. & He is not the kind of man in this new era. & $\sqrt{ }$ & \\
\hline 28. & No! I mean... Yes. & Beck could control his own head. & $\sqrt{ }$ & \\
\hline 29. & Personal connection? & Boys imagining vulgar things is a natural thing & & $\sqrt{ }$ \\
\hline 30. & Okay. Now I'm sending you both to hell. & $\begin{array}{l}\text { Beck felt underestimated and was tired of } \\
\text { unimportant questions. }\end{array}$ & & $\sqrt{ }$ \\
\hline 31. & Yes, yes, we're way into it. & John will ask that question. & & $\sqrt{ }$ \\
\hline 32. & What are you talking about? & $\begin{array}{l}\text { Beck tried to answer this kind of unimportant } \\
\text { question. }\end{array}$ & & $\sqrt{ }$ \\
\hline 33. & $\begin{array}{l}\text { It's full of puritans, who were the most } \\
\text { sexually repressed people in history. }\end{array}$ & People cannot be separated from history. & & $\sqrt{ }$ \\
\hline
\end{tabular}




\begin{tabular}{|c|c|c|c|c|}
\hline 34. & $\begin{array}{l}\text { At the souvenir store and time square during } \\
\text { the pandemic. Aaaa it's not great. }\end{array}$ & His business was getting worse. & $\sqrt{ }$ & \\
\hline 35. & $\begin{array}{l}\text { Actually, you're right. Maybe I should try } \\
\text { them on first. }\end{array}$ & Pete will buy the expensive underpants. & & $\sqrt{ }$ \\
\hline 36. & Yeah. & Pete was sure to buy underpants. & & $\sqrt{ }$ \\
\hline 37. & $\begin{array}{l}\text { Yeah, I love New York and I want my } \\
\text { modest bulge to show that. }\end{array}$ & $\begin{array}{l}\text { Whatever the reason, Pete really wanted to buy } \\
\text { the underpants. }\end{array}$ & $\sqrt{ }$ & \\
\hline 38. & That's what I want to know. & Kate was curious about that thing. & & $\sqrt{ }$ \\
\hline 39. & $\begin{array}{l}\text { Fools! You don't give up on my city that } \\
\text { easily. }\end{array}$ & Beggar and hobos did many activities to survive. & $\sqrt{ }$ & \\
\hline 40. & $\begin{array}{l}\text { Don't worry, that homeless guy staying at a } \\
\text { nearby luxury hotel will chase her off. }\end{array}$ & $\begin{array}{l}\text { The girl in front of the store would never enter } \\
\text { the store. }\end{array}$ & $\sqrt{ }$ & \\
\hline 41. & Get out of my store, get out of my store. & He did not know Rick Moranis. & & $\sqrt{ }$ \\
\hline 42. & I get it. & John did not need to explain it. & $\sqrt{ }$ & \\
\hline 43. & $\begin{array}{l}\text { And I'm especially hopeful now because we } \\
\text { only have three days more three more days } \\
\text { to the election. }\end{array}$ & Americans should prepare for election day. & $\sqrt{ }$ & \\
\hline 44. & Nope, nope, I'm good. & He did not have any idea. & $\sqrt{ }$ & \\
\hline 45. & $\begin{array}{l}\text { Fuck! Exhibit "A." My perfectly handsome } \\
\text { day in my profile pic is nothing to be } \\
\text { ashamed of. }\end{array}$ & John refused Chloe's statement. & $\sqrt{ }$ & \\
\hline 46. & Oh, really? & John doubted Chloe's statement. & & $\sqrt{ }$ \\
\hline 47. & Okay, that's creative. & He did not have any idea. & & $\sqrt{ }$ \\
\hline 48. & That's one of those default settings. & John did not want to offend his girl employees. & $\sqrt{ }$ & \\
\hline 49. & Tinder. & John did not use the website to find a girl. & $\sqrt{ }$ & \\
\hline 50. & I'm sorry what? & Chloe doubts Pete's statement. & & $\sqrt{ }$ \\
\hline
\end{tabular}

Note:

GCI: Generalized Conversational Implicatures

PCI: Particularized Conversational Implicatures

\section{B. Discussion}

This study investigates the choice of conversational implicatures used by all guests in the Saturday Night Live talk show Season 46 Episode 5. The talk show used informal English and lasted for 1 hour 9 minutes 1 second. During this duration, we noted and listened to the utterances they produced to find out the types of conversational implicatures they uttered.

21 data containing generalized conversational implicatures were found. General conversational implicature is the type of implicature in which the listener does not require uncommon information to decipher the meaning since the setting utilized in this sort is common. According to Saragi (2011), generalized conversational implicature refers to flouted utterances that listeners can immediately understand without any special contextual analysis needed. Similarly, generalized conversational implicature occurs when the hearer does not need any special knowledge to estimate the conveyed meaning (Al, 2020). We explained the data further in the discussion below.

Datum \#1

Jim: "He made me scared of four years more." Quote the Clinton.

Kate: We lost before.

By violating the maxim of quantity, Kate implied that a classic poem by Edgar Allan Poe "The Raven" is one of the famous scary stories in the 1800s. This sentence contains generalized conversational implicatures since Kate's flouted utterance does not need any specific context to be understood. It means that the story can make people who read it soil their pantaloons because they are afraid of the story.

Datum \#5

Jim: I checked the website "FiveThirtyEight" to find out my election fate. Nate silver, he will know the score, even though...

Kyle: I was wrong before.

By violating the maxim of quantity, Kyle implied that he wants to clarify the information. Kyle's utterance belongs to generalized conversational implicatures since it can be directly understood.

Shifting toward the discussion of particularized conversational implicature, it is in contrast with the generalized ones (Al, 2020). Particularized conversational implicature refers to the implicatures in which context and particularity are not general in nature and therefore requires the listeners to imply meaning based on the context. For non-native speakers of English, understanding particularized conversational implicature involves the process of understanding the context which they do not usually share in their social background, so they require more assistance to estimate such deviated utterances (see Suryadi \& Muslim, 2019). 29 data containing particularized conversational implicatures were found. We explained the data further in the discussion below.

Datum \#8

Jim: Why in the name of all that is holy would you be voting for trump?

Michael \& Chris: Taxes. 
By violating the maxim of quantity, Michael \& Chris' utterance implied that Americans have a problem related to taxation. The utterance above is an example of irony since Michael \& Chris uttered "taxes". Donald Trump is teased by Michael \& Chris since the rate of taxes in America depends on individual income and also people have higher credit and deductions that reduce people's income.

Datum \#10

Michael: If you got a platinum record, you can plan on him doing a photo with you.

Jim: Trump cannot win. We must do better than that spray tan super spreader. I will win because I'm a baller.

By violating the maxim of relevance, Jim implied that Joe Biden is better than Donald Trump. This kind of utterance belongs to particularized conversational implicature since Jim's utterance contains hyperbole which means that the information is given in exaggeration. From these utterances, it can be said that people need specific context to understand the particularized conversational implicatures.

Four examples presented in the discussions above represented how we analyzed the whole data found in the Saturday Night Live talk show Season 46 Episode 5.

\section{CONCLUSION}

This research aimed to find out types of conversational implicatures found on Saturday Night Live talk show Season 46 Episode 5. We found 50 utterances containing conversational implicatures. In analyzing the data, Grice's theory of conversational implicatures was used to categorize the types of conversational implicatures. 21 data were containing generalized conversational implicatures and 29 data containing particularized conversational implicatures. We concluded that particularized conversational implicature was the most dominant implicature used in Saturday Night Live talk show Season 46 Episode 5. This finding reflects that people need specific context in doing interaction, especially in informal communication.

\section{REFERENCES}

[1] Alfina, E. O. (2016). The Maxim Violation on Mata Najwa Talk Show "Selebriti Pengganda Simpati” Unpublished Doctoral Thesis. Semarang: Diponogoro University.

[2] Al, R. A. (2020). An Analysis of Implicatures Found in Whatsapp Stories. Prosidi, 14 (1), 65-71.

[3] Arafah, B, \& Hasyim, M. (2019) Linguistic Functions of Emoji in Social Media Communication. Opcion. Volume 35, No. 24, 558-574.

[4] Arafah, B., \& Hasyim, M. (2020). Covid-19 Mythology and Netizens Parrhesia Ideological Effects of Coronavirus Myths on Social Media Users. Palarch's Journal of Archaeology of Egypt/Egyptology. Volume 17 Issue 4, 1398-1409

[5] Arafah, B., \& Kaharuddin, A. (2019). The Representation of Complaints in English and Indonesian Discourses. Opción, Volume 35, 501-517.

[6] Arafah, B., Thayyib, M., Kaharuddin, \& Sahib, H. (2020). An Anthropological Linguistic Study on Maccera' Bulung Ritual. Opción, 36 (27), 1592-1606.

[7] Arafah, K., Arafah, A.N.B., \& Arafah, B. (2020). Self-Concept and Self-Efficacy's Role in Achievement Motivation and Physics Learning Outcomes. Opción, 36 (27), 1607-1623.

[8] Birner, B. J. (2012). Introduction to Pragmatics. Vol. 38. Oxford: Wiley-Blackwell.

[9] Brown, G \& Yule, G. (1983). Teaching the Spoken Language. Cambridge: Cambridge University Press.

[10] Clark, H. H. (1996). Using Language. Cambridge: Cambridge University Press.

[11] Crystal, D. A. (2008). Dictionary of Linguistics and Phonetics. 6th Edition. Oxford: Blackwell Publishing.

[12] Crowley, D. J., \& Mitchell, D. (Eds.). (1994). Communication Theory Today. Redwood City: Stanford University Press.

[13] Cutting, J. (2002). Pragmatics and Discourse. London: Routledge

[14] Cutting, J. (2008). Pragmatics and Discourse. London: Routledge

[15] Green, G. M. (1990). The Universality of Gricean Interpretation. Annual Meeting of the Berkeley Linguistics Society. Vol. 16, No. 1, 411-428.

[16] Green, G. M. (2012). Pragmatics and Natural Language Understanding. London: Routledge.

[17] Grice, H. P. (1975). Logic and Conversation. Cambridge: Harvard University Press.

[18] Grice, P. (1989). Studies in the Way of Words. Cambridge: Harvard University Press.

[19] Griffiths, P. (2006). Introduction to English Semantics and Pragmatics. Edinburgh: Edinburgh University Press.

[20] Grundy, P. (2000). Doing Pragmatics. London: Arnold

[21] Gunarwan. (1994). Pragmatik. Jakarta: Lembaga Bahasa Unika Atmajaya.

[22] Hasjim, M., et al. (2020). Principles Behind Semantic Relation between Common Abbreviations and their Expansions on Instagram. International Journal of Criminology and Sociology. Volume 9, 2270-2276.

[23] Hasyim, M., et al. (2020). The New Toraja Destination: Adding Value 'Toraja Coffee' of the Sustainable Tourism Development. IOP Conf. Ser.: Earth Environ. Sci. 575012072

[24] Horn, L. R. (1988). Pragmatic Theory. Linguistics: the Cambridge Survey, 1, 113-145.

[25] Horn, L. R. (2004). Implicature in L. Horn and G. Ward (eds), Handbook of Pragmatics, Oxford: Wiley-Blackwell

[26] Jordà, M. P. S. (2005). Third Language Learners: Pragmatic Production and Awareness. Clevedon, Buffalo: Multilingual Matters.

[27] Kaharuddin, K., \& Rahmadana, A. (2020). Problem-Based Group Discussion: An Effective ELT Technique to Improve Vocational High School Students' Transactional Speaking Skills. Jurnal Ilmu Budaya, 8 (2), 247-258. 
[28] Kamridah, A. H. Yassi., Arafah, B., \& Imran, N. (2016). Correlation between Level of Anxiety and Public Speaking Performance through Systematic Learning Approach in Foreign Language. International Journal of Science and Research (IJSR), 5(9), 1658-1663.

[29] Lakoff, R. T. (1989). The Limit of Politeness: Therapeutic and Courtroom Discourse. Multilingual Journal of Cross-Cultural and Interlanguage Communication, 8 (2-3), 101-130.

[30] Levinson, Stephen C. (1983). Pragmatics. Cambridge: Cambridge University Press.

[31] Levinson, Stephen C. (1989). Pragmatics. Cambridge: Cambridge University Press

[32] Levinson, S. C., Stephen, C., \& Levinson, S. C. (2000a). Presumptive Meanings: The Theory of Generalized Conversational Implicature. Cambridge: MIT Press.

[33] Levinson, S. C. (2000b). Conversational Implicatures in Pragmatics. Cambridge: Cambridge University Press

[34] Lindblom, K. (2001). Cooperating with Grice: A Cross-Disciplinary Meta perspective on Uses of Grice's Cooperative Principle. Journal of Pragmatics, 33 (10), 1601-1623.

[35] Mey, J. (2004). Pragmatics; An Introduction. Malden, MA: Blackwell.

[36] Paltridge. (2006). Discourse Analysis. London: Continuum

[37] Purwaningsih, Y. R., Arafah, B., \& Abbas, H. (2020). An Ambition of Infidelity "Emma Bovary" as Wife: Sexuality Problems. Medicina Clínica Práctica, 3 (S1):100108, 1-3.

[38] Saragi, Y. M. (2011). Flouting Maxims in Conversational Implicatures in the Elle Degenerates Talk Show. Surabaya: State University of Surabaya

[39] Sobhani, A., \& Saghebi, A. (2014). The Violation of Cooperative Principles and Four Maxims in Iranian Psychological Consultation. Open Journal of Modern Linguistics, 4 (1), 91-99.

[40] Sperber, D., and Wilson, D. (1986). Relevance. Oxford: Blackwell

[41] Suryadi, H., \& Muslim, M. (2019). An Analysis of Conversational Implicature Strategy in A Drama "the bear" by Anton Chekhov and its Application in ELT. Journal of Languages and Language Teaching, 7 (2), 82-95.

[42] Thomas, J. (1995). Meaning in Interaction: An Introduction to Pragmatic. London: Longman

[43] Virgin, J. A., \& Utami, C. P. (2016). Dominant Maxim violations in 'Behind the Lawyer Profession'of Hitam Putih Talk Show. Proceedings of the $9^{\text {th }}$ International Conference on Applied Linguistics (CONAPLIN 9), Advances in Social Science, Education, and Humanities Research (ASSEHR), Vol. 82, 185-188.

[44] Verschueren, J. (1999). Understanding Pragmatics. London: Arnold.

[45] Wishnoff, R. J. (2000). Hedging Your Bets: L2 Learners' Acquisition of Pragmatic Devices in Academic Writing and Computer-Mediated Discourse. Second Language Studies, 19,127157.

[46] Yule, G. (1996). Pragmatics. Oxford: Oxford University Press

[47] Yule, G. (2006). The Study of Language. $3^{\text {rd }}$ Edition. New York: Cambridge University Press.

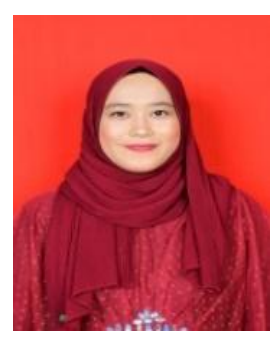

Sri Yulianti obtained her bachelor's degree in English Language and Literature Department, Faculty of Adab and Humanities, Alauddin State Islamic University of Makassar (UIN Alauddin Makassar) in 2018. She completed her master's degree in English Language Studies Program, majoring in Linguistics at Postgraduate Program of Faculty of Cultural Science, Hasanuddin University (UNHAS) Indonesia in 2021.

Her scholarly interest includes linguistics, communication science, and artistry. The focus of her master's research is the usage of language in informal communication.

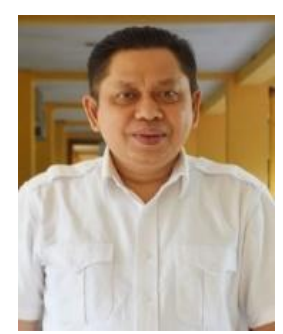

Burhanuddin Arafah obtained his Ph.D. degree in English (Australian) literature at the University of Newcastle Australia in 2003. He earned his Master's degree in American literature at Gadjah Mada University (UGM) Yogyakarta of Indonesia in 1995, and his Bachelor's degree in English literature at Hasanuddin University (UNHAS) in 1988.

He is currently a full Professor in English literature at the English Literature Study Program, Faculty of Cultural Sciences of Hasanuddin University (UNHAS) Indonesia. He has published 4 books in English language and literature and more than 50 research articles ranked international journals published in the English language. He also has received 24 Intellectual Property Right Certificates from the Indonesian government. His areas of interest are English literature, language education, and cultural studies. He was the Dean of the Faculty of Cultural Sciences of Hasanuddin University in 2009-2017, and currently, he is actively involved at the National Accreditation Board-Higher Education, Ministry of Education and Culture of the Republic of Indonesia for his position as Assessor.

Professor Arafah is currently a member of the Indonesian Literature Scholar Association, and Linguistics and Literature Association of Indonesia, as well as actively involved in the Indonesian Linguistics Society Association. 


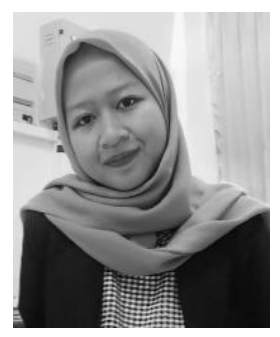

Ummu Rofikah is currently a Postgraduate student majoring in English Education at Hasanuddin University (UNHAS). She completed her Bachelor's degree in English Language Education at Alauddin State Islamic University of Makassar (UIN Alauddin Makassar) in 2019.

Her scholarly interests include English Language Teaching, Materials Development, Academic Writing, Second Language Acquisition, Computer Assisted Language Learning, Literature, and Feminism. Her recent publication is entitled "The IDOL: An Innovative Model for Designing Literature-Based ELT Materials", published in Linguistica Antverpiensia, in March 2021.

Ms. Rofikah involves herself in several seminars, and international conferences as a presenter, a participant, and a committee. To contribute to the community, she also actively participates as an education activist in several education-related organizations in Makassar, and actively shares her knowledge through online classes, and webinars. She is looking forward to pursuing her second Master's degree abroad.

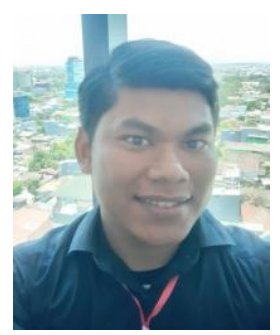

Andi Muhammad Syafri Idris obtained his bachelor's degree in English Language Education at IAIN Parepare, South Sulawesi of Indonesia in 2017. He earned his master's degree in English Language Studies Program, majoring in English Education at Postgraduate Program of Faculty of Cultural Science, Hasanuddin University (UNHAS) Indonesia in 2021.

He participated in some international conferences, such as ICLC (International Conference on Linguistics and Cultural Studies) in 2019, and ICONELE (International Conference on English Language Education) in 2020. His areas of interest include Second Language Acquisition, Education and Research, and Sociolinguistics fields.

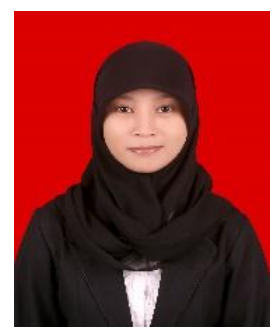

Nurfaizah Samsur is currently pursuing her Master's degree at Hasanuddin University majoring in English Language Studies. She got her bachelor's degree in English Language and Literature at UIN Alauddin Makassar in 2014.

Her scholarly interests include intercultural communication, American and British English studies, and the LBC (linguistic-based cues) of deception by either native or non-native English speakers which she is currently working on. She focuses her study more on written languages (textual media) and transcribed conversations to observe the language phenomena.

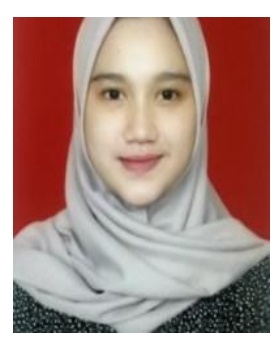

Azhariah Nur B. Arafah is currently a lecturer and Doctoral student in Psychology at Gunadarma University (UG) Jakarta of Indonesia. She obtained her MA degree in Clinical Psychology at Gadjah Mada University (UGM) Yogyakarta in 2020 and earned her Bachelor's degree in Psychology at Hasanuddin University (UNHAS) Makassar in 2017. She wrote some research articles ranked international journals published both in the English and Indonesian languages.

Her areas of interest are Clinical Psychology, Social Psychology, and Interpersonal Relationships. She is also actively spreading awareness about Mental Health on social media (@aware.nessid). 